УДК 622.232

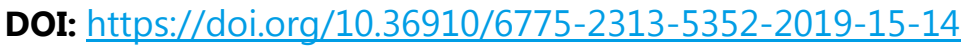

Стасюк В.М., к.T.н.

Луцький національний технічний університет

\title{
ДИНАМІКА ПІДКРИТИЧНОГО РЕЖИМУ ПНЕВМОМЕХАНІЧНИХ ПРИВОДІВ МАШИН УДАРНОї ДІї
}

Завдання підвищення надійності пневматичних машин ударної дї̈ завжди залишалося та залитається актуальним, зокрема і тих із них, що оснащені приводами із пневмомеханічними системами керування. Це стосується як надкритичного, так і підкритичного режимів їх експлуатаціï.

У даній статті виконані дослідження підкритичного режиму. 3 метою встановлення стійкості функиіонування вищезазначеного приводу досліджено динаміку зміни тиску в його робочих камерах на фазах їх наповнення та спорожнення з використанням сталої часу інериійної ланки, величини провідності впускного елемента пневмомеханічної системи керування, коефіцієнта витрат системи повітророзподілу, сталих часу наповнення та спорожнення, а також функції співвідношення тисків при наповненні пневмокамери при підкритичному режимі надходження енергоносія та функиї співвідношення тисків при спорожненні пневмокамери при підкритичному режимі випуску відпращьованого повітря.

Використовуючи отримані результати досліджень, можна иляхом раціонального підбору розмірів конструктивних елементів пневмомеханічної системи повітророзподілу та параметрів робочих $і$ компенсачійних камер істотно впливати на стійкість роботи пневмомеханічних приводів у підкритичному режимі.

Доведено, що у проиесі проведення досліджень варто також враховувати специфіку контактної взаємодії штока клапанного механізму з поршнем-ударником. Адже від надійності спрацювання клапанного механізму на початку фаз впуску-випуску енергоносія істотно залежить надійність машини ударної дї під час ї̈ експлуатації.

Ключові слова: пневмопривод, підкритичний режим, енергоносій, стиснене повітря, поршень-ударник.

Постановка проблеми. Надходження стисненого повітря у робочі камери приводів із пневмомеханічним керуванням та його випуск протягом робочого циклу здійснюється як у підкритичному, так і у надкритичному режимах. Відмови в роботі таких приводів можливі через специфіку підкритичного режиму.

Аналіз останніх досліджень i публікацій. Окремі аспекти роботи пневматичних приводів при підкритичному та надкритичному режимах надходження та випуску енергоносія розглядаються у роботах [1-4]. Однак про особливості динаміки підкритичних і надкритичних режимів пневмомеханічних приводів у них не йдеться.

Формулювання цілей статті. Дослідити динаміку підкритичного режиму пневмомеханічних приводів з метою можливості конструктивного забезпечення його стійкості.

Результати досліджень. У цій роботі наведені кінцеві результати теоретичних досліджень підкритичного режиму пневмомеханічних приводів без проміжних виведень та розрахунків. При цьому за основу прийняті методики, запропоновані у роботах [1-4].

Досить повно динаміку зміни тиску в робочій камері змінного об'єму пневматичного приводу із пневмомеханічним керуванням при підкритичному режимі її наповнення стисненим повітрям можна описати формулою:

$$
\frac{d p_{H}}{d t}=\frac{\left(p_{M}-p_{a}\right) \Phi(x, \dot{x}, t) \psi_{1}(\sigma) p_{M} \sigma}{\sigma^{2} p_{M}-\left(p_{M}-p_{a}\right) \theta(x, t)\left[\frac{\varphi\left(\sigma_{*}\right) \sigma^{\frac{k-1}{k}}}{\sqrt{1-\sigma^{\frac{k-1}{k}}}}-\psi_{1}(\sigma)\right]},
$$

де $\frac{d p_{H}}{d t}-$ зміна тиску в робочій камері змінного об'єму пневматичного приводу із пневмомеханічним керуванням при підкритичному режимі ії наповнення;

$$
p_{M} \text { - тиск живлення системи; }
$$


$p_{a}$ - атмосферний тиск;

$\Phi(x, \dot{x}, t)=\frac{d \theta(x, t)}{d t}$, де $\theta(x, t)=1-e^{-\frac{t}{\tau_{0} F\left(x_{0}+x\right)}}\left(t-\right.$ стала часу інерційної ланки: $t=\frac{V}{R T_{M} \alpha}$, де $V$ - об'єм камери наповнення; $R$ - газова стала; $T_{M}$ - абсолютна температура повітря в камері наповнення; $\alpha$ - провідність впускного елемента системи повітророзподілу, через який стиснене повітря із пневмолінії надходить у камеру наповнення; $\tau_{0}$ - стала часу наповнення; $F$ - площа поперечного перерізу суцільноцилідричної частини поршня-ударника; $x_{0}$ - початкова координата поршня-ударника, яка визначає компенсаційний об'єм камери наповнення; $x$ поточна координата поршня-ударника);

$\psi_{1}(\sigma)$ - функція співвідношення тисків при наповненні пневмокамери;

$\sigma=\frac{p_{H}}{p_{M}}-$ співвідношення тиску в камері наповнення $p_{H}$ до тиску живлення $p_{M}$;

$\varphi\left(\sigma_{*}\right)$ - функція витрати при критичному співвідношенні тисків під час наповнення камери ( $\sigma_{*}=\frac{p_{*}}{p_{M}}-$ критичне співвідношення тисків при наповненні камери; $p_{*}-$ критичний тиск);

$k-$ показник адіабати.

Для визначення величини провідності $\alpha$ впускного елемента системи повітророзподілу, через який стиснене повітря із пневмолінії надходить у камеру наповнення, варто використовувати наступну залежність:

$$
\alpha=\frac{\mu f K p_{M} \varphi(\sigma) \sqrt{\frac{1}{R T_{M}}}}{\sqrt{p_{M}-p}}
$$

де $\mu$ - коефіцієнт витрат системи повітророзподілу;

$f$ - площа робочих перерізів конструктивних елементів системи повітророзподілу, які забезпечують надходження стисненого повітря у робочу камеру;

$K=\sqrt{\frac{2 k}{k-1}}-$ коефіцієнт;

$p$ - тиск повітря у камері наповнення;

$\varphi(\sigma)$ - функція співвідношення тиску в камері та тиску живлення.

Коефіцієнт витрат системи повітророзподілу $\mu$ для підкритичного режиму наповнення робочої камери:

$$
\mu=\frac{\left(1-\sigma_{a}\right) e^{-\frac{t}{\tau_{0} V}}}{k K \varphi(\sigma) \tau_{0} \sigma_{H k} f \sqrt{R T_{M}}} \cdot\left[\frac{\left(\sigma_{H k}-\sigma_{a}\right) \varphi\left(\sigma_{*}\right)}{\varphi(\sigma)}+\frac{\sigma_{a}}{\sigma_{H k}} \psi_{1}\left(\sigma_{H k}\right)\right]
$$

де $\sigma_{a}=p_{a} / p_{M}$;

$t=V / R T_{M} \alpha$

$\sigma_{H k}-$ співвідношення тисків на завершальній фазі наповнення;

$\psi_{1}\left(\sigma_{H k}\right)$ - функція співвідношення тисків на завершальній фазі наповнення;

Функція співвідношення тисків при наповненні пневмокамери $\psi_{1}(\sigma)$ при підкритичному режимі надходження енергоносія описується формулою:

$$
\psi_{1}(\sigma)=\frac{2 k}{k-1} \varphi\left(\sigma_{*}\right)\left(\sqrt{1-\sigma_{*}^{\frac{k-1}{k}}}-\sqrt{1-\sigma^{\frac{k-1}{k}}}+\sigma_{*}\right) .
$$


Динаміку зміни тиску в робочій камері змінного об’єму пневматичного приводу із пневмомеханічним керуванням при підкритичному режимі іiі спорожнення можна описати наступною формулою:

$$
\begin{aligned}
\frac{d p_{B H}}{d t}= & \left(p_{M}-p_{a}\right) H(x, \dot{x}, t) \frac{\psi_{2}\left(\sigma_{B}\right)}{\sigma_{B}^{\frac{k-1}{2 k}}}+\left(p_{M}-p_{a}\right) R(x, t) \times \\
& \times \frac{\frac{d \psi_{2}\left(\sigma_{B}\right)}{d \sigma_{B}}-\psi_{2}\left(\sigma_{B}\right) \cdot \frac{k-1}{2 k} \cdot \sigma_{B}^{-\frac{k+1}{2 k}}}{\sigma_{B}^{\frac{k-1}{k}}} \cdot \frac{d \sigma_{B}}{d t},
\end{aligned}
$$

де $\frac{d p_{B H}}{d t}-$ зміна тиску в робочій камері змінного об'єму пневматичного приводу із пневмомеханічним керуванням при підкритичному режимі іï спорожнення;

$$
\left.H(x, \dot{x}, t)=\frac{d R(x)}{d t} \text {, де } R(x, t)=e^{-\frac{t}{\tau_{0 c} F\left(s+x_{0 c}-x\right)}}\right)\left(\tau_{0 c}-\text { стала часу спорожнення; } x_{0 c}\right. \text { - початкова }
$$

координата поршня-ударника, яка визначає компенсаційний об'єм камери спорожнення; $s$ - хід поршня-ударника);

$\psi_{2}\left(\sigma_{B}\right)$ - функція співвідношення тисків при спорожненні пневмокамери;

$\sigma_{B}=\frac{p_{a}}{p_{B}}-$ безрозмірний тиск у камері спорожнення;

$p_{B}$ - тиск випуску у камері спорожнення.

Функція співвідношення тисків при спорожненні пневмокамери $\psi_{2}\left(\sigma_{B}\right)$ при підкритичному режимі випуску відпрацьованого повітря описується формулою:

$$
\psi_{2}\left(\sigma_{B}\right)=\sigma_{B^{*}}^{\frac{k-1}{2 k}}+\frac{k-1}{2 k} \varphi\left(\sigma_{*}\right) \int_{\sigma_{B 1}}^{\sigma_{B 2}} \frac{d \sigma_{B}}{\sigma_{B}^{\frac{k+1}{2 k}}} \cdot \varphi(\sigma),
$$

де $\sigma_{B^{*}}-$ критичне співвідношення тисків при спорожненні пневмокамери;

$\varphi\left(\sigma_{*}\right)$ - функція витрати при критичному співвідношенні тисків під час спорожнення пневмокамери;

$\sigma_{B 1}, \sigma_{B 2}$ - безрозмірні тиски на початковому і кінцевому етапах процесу спорожнення;

$\varphi(\sigma)$ - функція співвідношення тисків при спорожненні пневмокамери.

Використовуючи результати вищенаведених досліджень, можна шляхом підбору розмірів конструктивних елементів системи повітророзподілу та робочих і компенсаційних камер істотно впливати на стійкість роботи пневмомеханічних приводів у підкритичному режимі.

Варто звернути також увагу на специфіку контактної взаємодії штока клапанного механізму впуску енергоносія та поршня-ударника. Від надійності спрацювання клапанного механізму під час цієї взаємодії залежить надійність роботи приводу та віброударної машини в цілому. Для зменшення сили ударного контакту штока і поршня-ударника на початковому етапі їх взаємодії та точкового контакту між ними на етапах впуску енергоносія у робочі камери торець штока виготовляється сферичним, а на торцях поршня-ударника виготовляються фаски.

Однак оскільки привод відноситься до високошвидкісних, а енергетичні характеристики віброударної машини, оснащеної ним, можуть істотно відрізнятися між собою, то руйнування або непридатність клапана внаслідок більш або менш інтенсивного зношування його штока може служити однією із найчастіших причин відмови у роботі пневмомеханічного привода. При цьому зона дії динамічних напруг локалізується безпосередньо на сферичній частині торця штока клапана. Проведені дослідження показують, що у 80-85 \% руйнування штока клапана відбувається внаслідок утоми через дію циклічних напруг.

Безпосередньо процес руйнування штока можна розглядати розподіленим на декілька етапів, першим з яких $є$ певне пластичне деформування поверхні торця штока в результаті 
ударної взаємодії з поршнем-ударником (яка відбувається 3 високою частотою протягом робочого циклу під час холостого ходу поршня-ударника), другим - поява мікротріщин у тілі штока в районі його сферичного торця, а третім - розростання зон (площ) пластичного деформування та/або поява більших за розмірами тріщин у тілі штока, що в кінцевому рахунку призводить до ускладнення/неможливості подальшої контактної взаємодії поршня-ударника та штока клапана або руйнування тіла штока клапана і відмови в роботі пневмомеханічного привода та віброударної машини в цілому.

Безумовно, 3 метою запобігання гірших наслідків експлуатацію віброударної машини доцільно припинити на початкових етапах руйнування штока клапана. Для цього, насамперед, шляхом проведення відповідних експериментальних потрібно визначити оптимальну кількість робочих циклів, після здійснення яких доцільно провести технічне обслуговування привода 3 метою заміни клапана механізму впуску енергоносія незалежно від стану тіла штока клапана та ступеня його зношення або етапу руйнування. Крім того, вищого ступеня надійності віброударних машин з пневмомеханічними приводами можна досягнути за рахунок дотримання жорстких вимог щодо виготовлення клапана механізму впуску енергоносія та поршняударника, їх матеріалу та термообробки.

Варто також зважати, що від розмірів конструктивних параметрів привода залежать величини робочих характеристик віброударної машини. Це також стосується і розглядуваних вище тіл ударної взаємодії - поршня-ударника та клапана механізму впуску енергоносія. Наприклад, від величини кута $\beta$ нахилу фасок поршня-ударника залежить тривалість впуску стисненого повітря в робочі камери та лінійні розміри самого поршня-ударника (а, відповідно, його об'єм та маса), оскільки довжина $l_{\Pi}$ поршня-ударника:

$$
l_{\Pi}=l_{\Pi 1}+2 l_{\Pi \Phi}=l_{\Pi 1}+2 h_{l} \operatorname{ctg} \beta,
$$

де $l_{\Pi 1}$ - довжина циліндричної частини поршня-ударника;

$l_{\text {ПФ }}$ - довжина фаски поршня-ударника;

$h_{1}$ - висота фаски поршня-ударника.

Щодо діаметра штока клапана/клапанів $d_{\Psi}$, то він впливає на величину/величини діаметра/діаметрів робочого вікна (робочих вікон) $d_{K}$ впускного механізму:

$$
d_{K}=\sqrt{\frac{4 f}{\pi}}-d_{U},
$$

де $f$ - фактична площа (фактичні площі) прохідного перерізу (прохідних перерізів) робочого вікна (робочих вікон) впускного механізму:

$$
f_{4}^{\prime}=f_{5}^{\prime}=\frac{\pi \psi_{K \Pi} D^{2}}{4},
$$

де $\psi_{\text {кп }}=0,065 \ldots 0,08$ - коефіцієнт відношення площі перерізу підвідних каналів до площі перерізу поршня-ударника;

$D$ - діаметр поршня-ударника.

Висновок. Отримані залежності дозволяють оцінити стійкість підкритичного режиму пневмомеханічних приводів, що особливо важливо на етапі їх проектних розробок. Крім того, запропоновані підходи до оцінки надійності клапанного механізму впуску енергоносія 3 позицій інтенсивності зношування штока клапана.

\section{Інформаційні джерела}

1. Педченко М.Н., Радченко Г.Ф., Федорец В.А. К расчету пневматических емкостей // Пневматика и гидравлика. - 1977. - Вып. 4. - С. 268-271.

2. Элементы и системы пневмоавтоматики / Т.К. Берендс, Т.К. Ефремова, А.А. Тагаевская, С.А. Юдицкий. - М.: Машиностроение, 1976. - 246 с.

3. Педченко М.Н., Радченко Г.Ф., Федорец В.А. Определение пропускной способности пневматической линии выхлопа // Гидропривод и гидропневмоавтоматика: Респ. межвед. научн.-техн. сб. - 1975. - Вып. 12. - С. 48-55.

4. Расчет гидравлических и пневматических приводов гибких производственных систем / В.А. Федорец - К.: Вища шк., 1988. - 179 с. 
Стасюк В.М., к.т.н.

Луцкий национальный технический университет

\section{ДИНАМИКА ПОДКРИТИЧЕСКОГО РЕЖИМА ПНЕВМОМЕХАНИЧЕСКИХ ПРИВОДОВ МАШИН УДАРНОГО ДЕЙСТВИЯ}

Задание повышения надежности пневматических машин ударного действия всегда оставалось и остается актуальным, в том числе и тех из них, которые оснащены приводами с пневмомеханическими системами управления. Это касается как сверхкритического, так и подкритического режимов их эксплуатации.

В этой публикации выполнень исследования подкритического режима. С целью установления устойчивости функиионирования вышеупомянутого привода исследована динамика изменения давления в его рабочих камерах на фазах их наполнения и опорожнения с использованием постоянной времени инериионного звена, проводимости впускного элемента пневмомеханической системы управления, коэффициента расхода системы воздухораспределения, постоянных времени наполнения и опорожнения, а также функции соотнотения давлений при наполнении пневмокамеры при подкритическом режиме поступлении энергоносителя и функции соотнотения давлений при опорожнении пневмокамеры при подкритическом режиме выпуска отработанного воздуха.

Используя полученные результаты исследований, можно путем рачионального подбора размеров конструктивных элементов пневмомеханической системы воздухораспределения $u$ параметров рабочих и компенсационных камер существенно влиять на устойчивость работь пневмомеханических приводов в подкритическом режиме.

Доказано, что в процессе проведения исследований следует также учитывать специфику контактного взаимодействия штока клапанного механизма с поринем-ударником. Ведь от надежности срабатывания клапанного механизма в начале фаз впуска-выпуска энергоносителя существенно зависит надежность машины ударного действия во время ее эксплуатации.

Ключевые слова: пневмопривод, подкритический режим, энергоноситель, сжатый воздух, поршень-ударник.

\section{Stasiuk V.M.}

Lutsk National Technical University

\section{DYNAMICS OF SUB-CRITICAL MODE OF PNEUMATIC MECHANICAL DRIVES OF PERCUSSIOM MASHINES}

The task of improving the reliability of pneumatic percussion machines has always been and is still being topical including those equipped with drives with pneumatic mechanical control systems. This applies to both supercritical and sub-critical modes of operation.

This article studies the sub-critical regime. In order to establish the stability of the abovementioned drive, the dynamics of pressure changes in its working chambers in the phases of their filling and emptying with the use of a steady time of the inertial link, the magnitude of the conduction of the inlet element of the pneumatic mechanical control system, the coefficient of flow of air distribution, and the stepping function, were investigated. The pressure ratio when filling the pneumatic chamber at sub-critical mode of energy supply and the function of the pressure ratio when emptying pneumatic chamber at sub-critical mode of exhaust air were examined.

Using the obtained research results, it is possible to significantly influence the stability of the operation of the pneumatic mechanical drives in the sub-critical mode by rationally selecting the sizes of the structural elements of the pneumatic mechanical air distribution system and the parameters of the working and compensation chambers.

It is proved that in the course of research it is also necessary to take into account the specificity of the contact interaction of the valve stem with the piston-drummer. After all, the reliability of the actuation of the valve mechanism at the beginning of the inlet-release phase of the energy carrier significantly depends on the reliability of the percussion machine during its operation.

Keywords: pneumatic drive, sub-critical mode, energy carrier, compressed air, pistondrummer. 